\title{
Notes on the vocalizations of Curve-billed Thrasher (Toxostoma curvirostre)
}

Peter Boesman

In the following we briefly analyze and compare voice of the different races of Curve-billed Thrasher (Toxostoma curvirostre). We also try to quantify the extent of any vocal differences using the criteria proposed by Tobias et al. (2010), as a support for taxonomic review. We have made use of sound recordings available on-line from Xeno Canto (XC).

The taxonomic situation of two groups (Eastern "nominate group" and less distinctly marked Western "palmeri group") has been discussed quite a bit in North-America. Related to voice, there has been a comparison of call notes, indicating a clear difference (Pieplow 2010, http://earbirding.com/blog/archives/2480):

palmeri group: call can be transcribed as "wi-weet" or "wi-weet-weet"

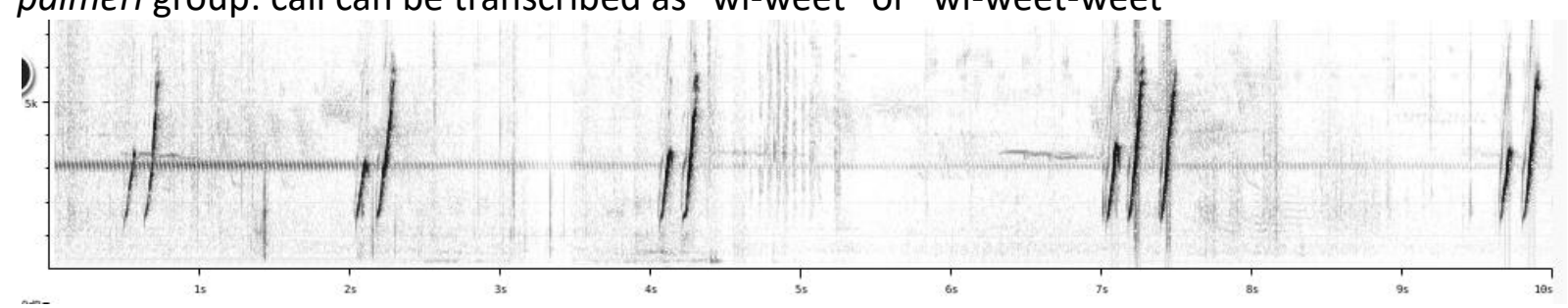

curvirostre group: call can be transcribed as "weet-a-weet" or "weet-weet"
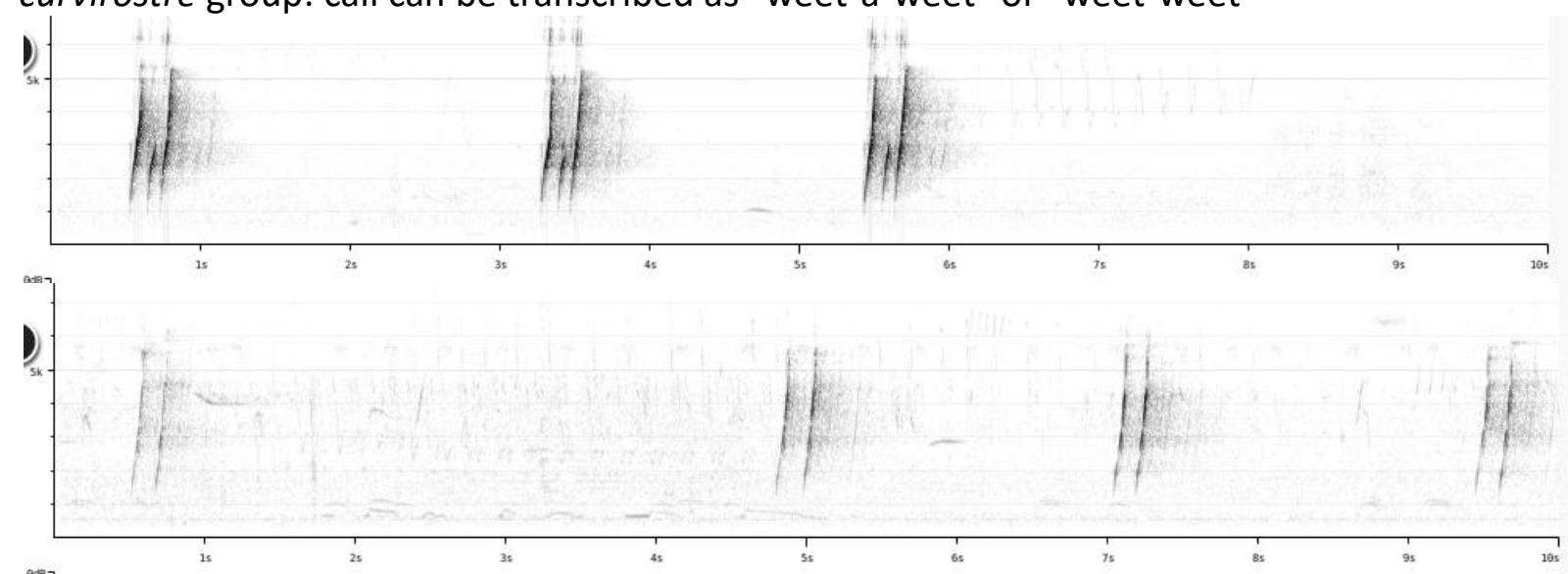

This difference can also be confirmed in Mexico, with birds of NW Mexico (S to Sinaloa) uttering the 'wi-weet' call.

A comparison of song would be much more complex, given the large variation of notes and phrases (and it is already far from straightforward to formulate objective and measurable distinguishing features from other members of the genus e.g. Bendire's Thrasher T. bendirei). It is said that eastern group mimics other species, while this has not been documented for the western group (Cody 2016). 

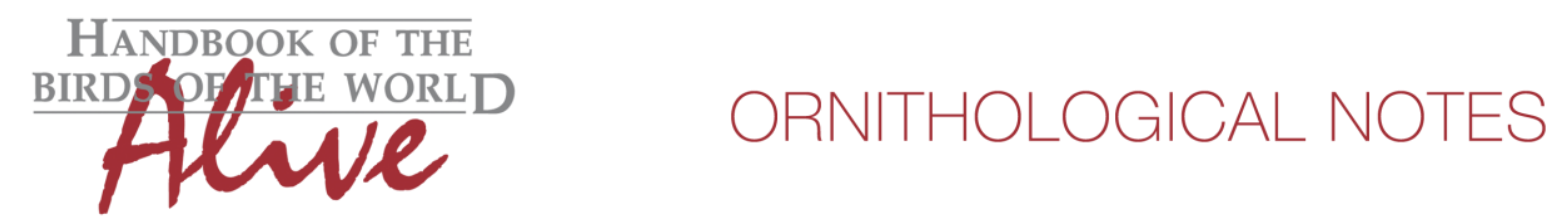

If we would score vocal difference purely based on this call note, there would thus be a measurable difference in e.g. freq. range of the first note (being smallest in the palmeri group, score 3). It should be noted however that this is a score for a vocalization other than the territorial song.

As a final remark, it is interesting to note that the Oaxaca population (presently not considered a distinct taxon, and included in race curvirostre) is genetically distinct but closest to the eastern group (Rojas-Soto et al. 2007).

Surprisingly, the call seems to be also distinct $(n=1)$ :

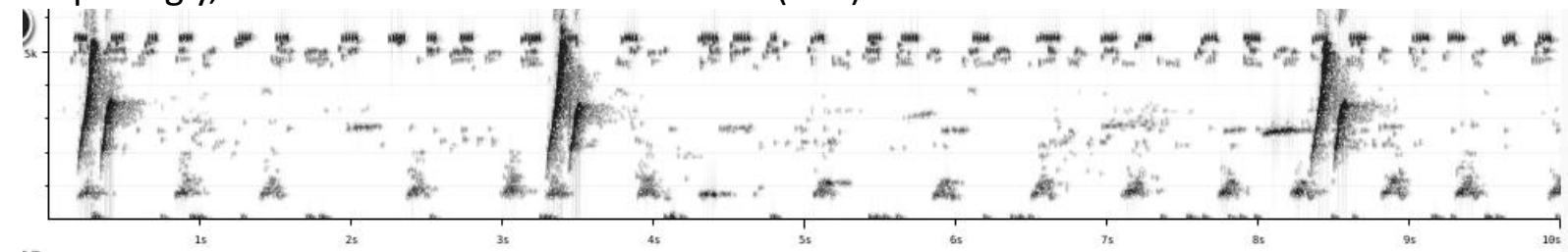

with the last note in the call having the smallest frequency range, unlike both other groups.

This note was finalized on 18th April 2016, using sound recordings available on-line at that moment. We would like to thank in particular the many sound recordists who placed their recordings for this species on XC.

\section{References}

Cody, M. (2016). Curve-billed Thrasher (Toxostoma curvirostre). In: del Hoyo, J., Elliott, A., Sargatal, J., Christie, D.A. \& de Juana, E. (eds.). Handbook of the Birds of the World Alive. Lynx Edicions, Barcelona. (retrieved from http://www.hbw.com/node/58207 on 18 April 2016).

Rojas-Soto, O.R., Espinosa de los Monteros, A. and Zink, R.M. (2007). Phylogeography and patterns of differentiation in the Curve-billed Thrasher. Condor 109: 456-463.

Tobias, J.A., Seddon, N., Spottiswoode, C.N., Pilgrim, J.D., Fishpool, L.D.C. \& Collar, N.J. (2010). Quantitative criteria for species delimitation. Ibis 152(4): 724-746.

\section{Recommended citation}

Boesman, P. (2016). Notes on the vocalizations of Curve-billed Thrasher (Toxostoma curvirostre). HBW Alive Ornithological Note 299. In: Handbook of the Birds of the World Alive. Lynx Edicions, Barcelona. (retrieved from http://www.hbw.com/node/1251749 on 13 October 2016). 